\title{
Challenging homografts as the holy grail for aortic valve endocarditis
}

\author{
James K. Kirklin, MD
}

From the Department of Surgery, University of Alabama in Birmingham, Birmingham, Ala.

Disclosures: Author has nothing to disclose with regard to commercial support.

Received for publication Dec 8, 2015; accepted for publication Dec 8, 2015; available ahead of print Jan 9, 2016.

Address for reprints: James K. Kirklin, MD, University of Alabama in Birmingham, Surgery, 739 Zeigler Building

UAB Station, Birmingham, AL 35294 (E-mail: jkirklin@uab.edu).

J Thorac Cardiovasc Surg 2016;151:1230-1

$0022-5223 / \$ 36.00$

Copyright (c) 2016 Published by Elsevier Inc. on behalf of The American Association for Thoracic Surgery

http://dx.doi.org/10.1016/j.jtcvs.2015.12.009

After the seminal contributions of Starr and colleagues ${ }^{1}$ and Harken and associates ${ }^{2}$ in introducing the ball-valve prosthesis in 1960, the first orthotopic insertions of an allograft valve were performed by Barratt-Boyes and Ross ${ }^{3}$ in 1962. Early aortic valve homografts were collected and implanted within days, but the logistic challenges gave way to clean collection and sterilization with $\beta$-propriolactone, ethylene oxide, or irradiation, ${ }^{4}$ and later with antibiotic sterilization. ${ }^{5}$ The current method of cryopreservation was introduced by O'Brien and associates ${ }^{6}$ in 1975. During the past 30 years, numerous authors have documented acceptable midterm durability among patients aged 20 to 30 years and older.

Because of the more demanding surgical techniques involved in the implantation of aortic valve homografts compared with stented bioprosthetic and mechanical valves, coupled with the absence of readily available homograft valves at many centers, the "art" of aortic homograft surgery is often absent from the surgical repertoire of many adult cardiac surgeons. In view of the prevailing opinion among many surgical experts that aortic homografts offer the best protection against recurrent aortic root infection, many patients with aortic valve endocarditis are referred to centers with homograft expertise and availability.

The study by Kim and colleagues in this issue of The Journal of Thoracic and Cardiovascular Surgery is the latest in a series of reports ${ }^{8,9}$ challenging the incremental benefit of the aortic valve homograft in preventing recurrent infection of the aortic valve and aortic root relative to other prosthetic valve choices. This study is convincing from an analytic perspective, but propensity matching does not fully account for surgeon bias in selecting the valve substitute that he or she believes will provide the greatest protection against recurrent endocarditis. The major increase in the proportion of patients receiving homografts who had abscess formation $(67 \%$ vs $41 \%$ for mechanical valve and $30 \%$ for xenograft valves; $P<.001$ ) or infection with methicillinresistant Staphylococcus $(26 \%$ vs $13 \%$ for mechanical calves and $12 \%$ for xenograft valves) leads the reader at least to consider the possibility that homografts were more likely to be used in the most severely infected patients.

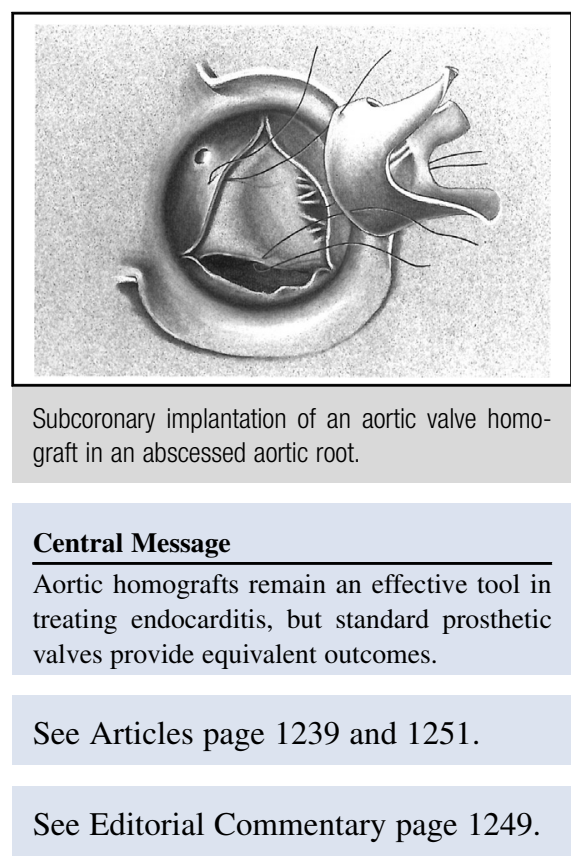

It is also notable in this study that $99 \%$ of the homografts were implanted as full root replacements, whereas fewer than $20 \%$ of either prosthetic valve type had root replacements. Some experienced homograft surgeons have preferred the intraaortic cylinder technique or infracoronary implantation (Figure 1), ${ }^{10}$ which avoids the short-term and longer-term complexities of full root replacement and has demonstrated long-term structural durability equivalent to that of the full root replacement.

In the final analysis, experienced homograft surgeons may prefer the advantageous features of the homograft (relatively resistant to infection and easily adapted to severe root infection) for individual patients, particularly those with more severe infection with abscess formation. Of considerable importance, however, is the evidencebased conclusion that surgical referral of routine surgical aortic valve endocarditis to a center experienced with aortic homograft surgery is not necessary, and a justifiable expectation is that aortic valve endocarditis requiring operation can be safely and appropriately managed in centers with standard aortic valve surgery experience who do not have access to or experience with aortic valve homografts.

\section{References}

1. Starr A, Edwards ML, McCord CW, Griswold HE. Aortic replacement: clinical experience with a semirigid ball-valve prosthesis. Circulation. 1963;27: $779-83$. 

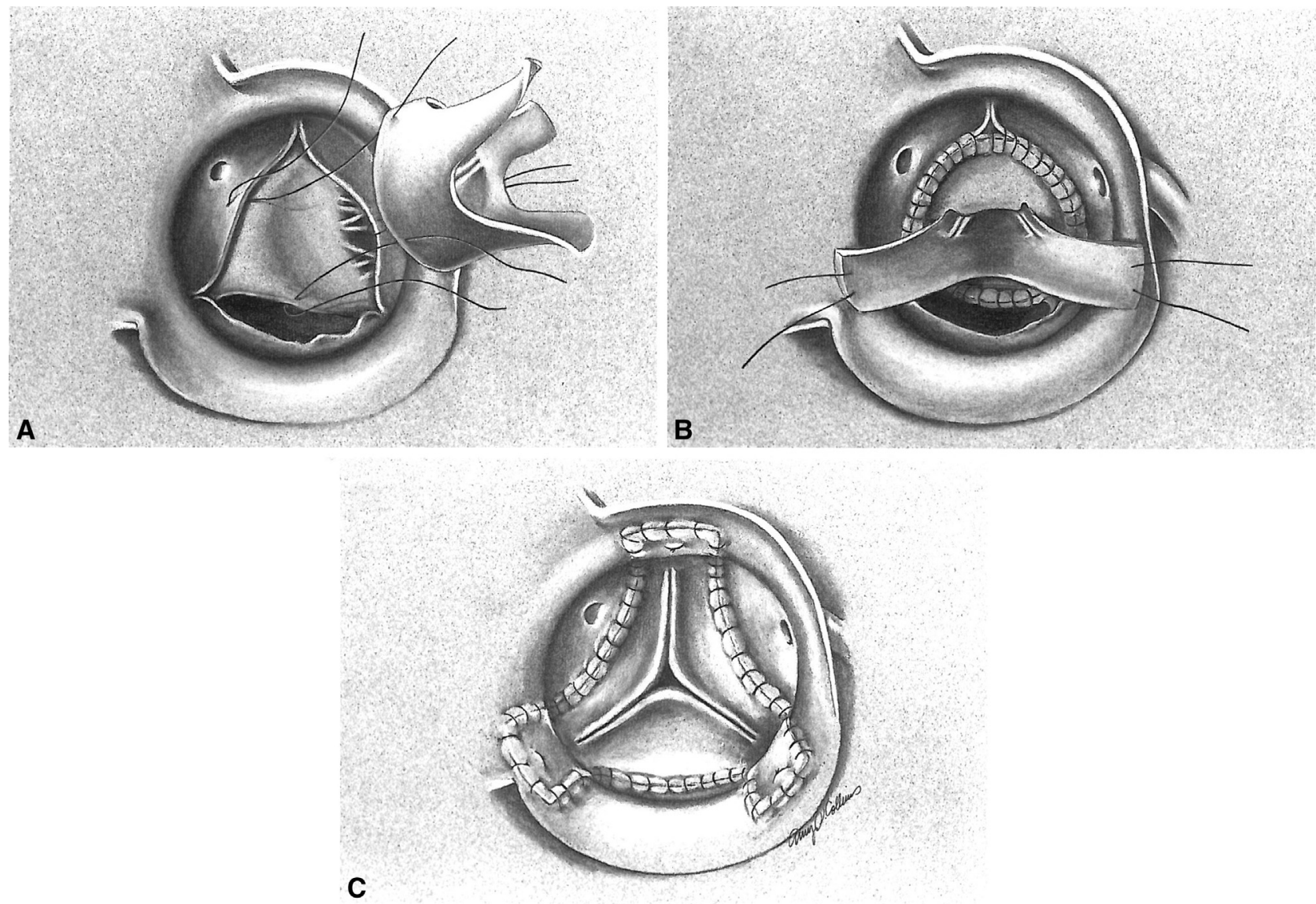

FIGURE 1. A-C, Infracoronary implantation of aortic valve homograft for extensive aortic root abscess.

2. Harken DE, Soroff HS, Taylor WJ, Lefemine AA, Gupta SK, Lunzer S. Partial and complete prostheses in aortic insufficiency. J Thorac Cardiovasc Surg. 1960;40:744-62.

3. Ross DN. Homograft replacement of the aortic valve. Lancet. 1962;2:487.

4. Hoeksima TD, Titus JL, Giuliani ER, Kirklin JW. Early results of use of homografts for replacement of the aortic valve in man. Circulation. 1967;35(4 Suppl):19-14.

5. Barratt-Boyes BG. Long-term follow-up of aortic valvar grafts. Br Heart J. 1971; 33(Suppl):60-5.

6. O'Brien MF, Stafford EG, Gardner MA, Pohlner PG, McGiffin DC. A comparison of aortic valve replacement with viable cryopreserved and fresh allograft valves, with a note on chromosomal studies. J Thorac Cardiovasc Surg. 1987; 94:812-23.
7. Fukushima S, Tesar PJ, Pearse B, Jalali H, Sparks L, Fraser JF, et al. Long-term clinical outcomes after aortic valve replacement using cryopreserved aortic allograft. J Thorac Cardiovasc Surg. 2014;148:65-72.e2.

8. Avierinos JF, Thuny F, Chalvignac V, Giorgi R, Tafanelli L, Casalta JP, et al. Surgical treatment of active aortic endocarditis: homografts are not the cornerstone of outcome. Ann Thorac Surg. 2007;84:1935-42.

9. Jassar AS, Bavaria JE, Szeto WY, Moeller PJ, Maniaci J, Milewski RK, et al. Graft selection for aortic root replacement in complex active endocarditis: does it matter? Ann Thorac Surg. 2012;93:480-7.

10. Kirklin JK, Kirklin JW, Pacifico AD. Aortic valve endocarditis with aortic root abscess cavity: surgical treatment with aortic valve homograft. Ann Thorac Surg. 1988;45:674-7. 